\title{
Host-Range, Distribution, and Bibliography of the Reniform Nematode, Rotylenchulus reniformis, with Special Reference to Puerto Rico
}

\author{
Alejandro Ayala and Carmen T. Ramirez ${ }^{1}$
}

\section{INTRODUCTION}

The reniform nematode, Rotylenchulus reniformis Linford and Oliveira, 1940 , described originally from Hawaii, is known to have a wide distribution in the Tropics and warmer parts of the Temperate Zone. For many years this species only was known. Recently four other species have been described: $R$. queirozi (Lordello and Cesnik, 1958) Sher 1961, from Brazil $(49)^{2} ; R$. parvus (Williams, 1959) Sher 1961, from Mauritius (88); $R$. borealis Loof and Oostenbrink, 1962 from the Netherlands (48); and $R$. leiperei (Das, 1960) Loof and Oostenbrink, 1962, from India (26).

Besides cowpeas, the type host of $R$. reniformis, 65 host plants were reported from Hawaii, in $1940(40,46)$. Also, the reniform nematode was identified as a parasite of cotton in Georgia by G. Steiner, as reported by Smith (75), which constitutes the first record from the United States. In 1942, Steiner (77) reported it attacking coffee weed and tomato in Florida. Subsequent reports have established its distribution in the Southern States from East to West including Florida (77), Georgia (75), Louisiana (76), Texas (4), Alabama (60) and California (2,52,71). It has also been reported from China (36); from meadows in the Netherlands (64); from Adansonia digitata L., Bambos vulgaris Schrad., and Zea mays L. in Rhodesia and Nyasaland; from several hosts in the Gold Coast (65); coconut palms in Togo, Ghana (51), and Jamaica (87); from Guam (69) and Pakistan (82); from tomatoes and papaws in Queensland, Australia (24) and citrus in Montserrat (67). In 1954, Tanaka (80) reported it from Japan; Loof and Oostenbrink, in 1962, from the Netherlands (48); Sasser et al., in 1962, from Perú (70); Das (26), in 1960, from India; Thorne (85), in 1961, from tobacco, clover, and tea from Java, and clover from Sumatra and the Philippines. It was also reported from Venezuela and Central America by Allen in a personal communication.

In Puerto Rico, the first report of the reniform nematode was made by Steiner in 1960 (79) as attacking pigeonpea, Cajanus indicus Spreng., and as being one of the most common nematode species in the Island. Several

${ }_{1}$ Assistant Nematologist and Former Research Assistant in Nematology of the Agricultural Experiment Station, Univ. P.R., Rio Piedras, P.R.

${ }_{2}^{2}$ Italic numbers in parentheses refer to Literature Cited pp. 155-61. 
other hosts were added in an anonymous publication in 1960 (4). In 1961, Román (68) reported its presence in sugarcane fields and Ayala (6) from pineapple fields, where it was found in large numbers, widely distributed.

During recent years numerous other plant species have been reported as affected by this parasite in Puerto Rico and elsewhere. The interest in the study of this group of parasitic nematodes has increased after several observations, the organism being associated with symptoms, crop damage, and disease complexes. For these reasons it was deemed important to bring together all scattered reports and to give general consideration to, and host range and distribution of the reniform nematode. This paper has been prepared with the purpose of giving an idea of the geographic distribution of the nematode and the plants susceptible to its attack under varied conditions. It is intended to serve as a guide for future investigations. A list of hosts gathered from almost all publications available to the authors, is presented herein, as well as the localities in which observations have been made, and the authority who first reported it. To facilitate checking of publications a general bibliography is also given in Literature Cited, pp. 155-61.

The results of studies conducted in Puerto Rico for determining host range are hereby included. Most of the observations were based on the recovery of preparasitic females, males, and juveniles from soil around plant roots, while in other cases controlled greenhouse experiments were conducted to determine susceptibility of plant species to the parasite. Samples were taken using the conventional sampling methods. The Baermann-funnel and modified screening petri-dish methods were used during most of the study for the separation of nematodes from the soil. In many instances roots were also used and in these cases they were broken up with a blendor. Since this method was not at all practical for recovering this nematode, the roots were incubated in petri-dishes and moist chambers, in most cases.

Another phase of the study consisted in the inoculation of roots with certain cultures of the nematode, especially from pigeonpeas, in the greenhouse. Plants were usually taken up after 3 months, when roots were examined directly under a low-power microscope. Viability of eggs was checked by placing opened egg masses in water for a short time, after which the eggs normally hatched. Roots were usually stained using the simplified lactophenol-acid fuchsin method to facilitate observations.

The plants were classified as susceptible, carriers, or resistant, according to the degree of susceptibility. Only those in which the nematode was able to produce viable eggs, even in small numbers, were classified as hosts. Plants in which the females were able to develop to maturity but did not produce eggs were classified as resistant or nonhosts. 


\section{HOST RANGE, DISTRIBUTION, AND LITERATURE CITED}

A list of the plants found to be hosts under Puerto Rican conditions was combined with the observations made by other investigators from different parts of the world.

The locality in which observations were made is given after the host's scientific and common names. The number given in parentheses corresponds with numbers in the Literature Cited and indicates the first report of the host in that locality. When no such number appears this indicates new host records from Puerto Rico and Caja de Muertos, a small Island south of Puerto Rico. Stars after numbers in parentheses indicate whether observations were made: Under field conditions only $\left({ }^{*}\right)$, under greenhouse conditions only $\left({ }^{* *}\right)$, or under both field and greenhouse conditions $\left({ }^{* * *}\right)$.

A list of the publications available, in which the reniform nematode is mentioned, is given. A short comment is also given on most of the publications, which may provide additional information to that given in the titles.

\section{HOST LIST AND DISTRIBUTION}

Rotylenchulus spp.

Scientific name

Abelmoschus esculentus (L.)

Moench.

Acanthus mollis $\mathrm{L}$.

Adansonia digitata $\mathrm{L}$.

Ananas sativus Schultes

Arecastrum romanzofianum

Becc.

Bambos vulgaris Schrad.

Cajanus indicus Spreng

Camellia spp.

Caryota mitis Lour.

C. urens L.

Chrysanthemum morifolium Ram.

Citrus spp.

C. mitis Blanco
Common name

Okra

Bear's-breech

Baobabtree

Pineapple

Bamboo

Pigeonpea

Camellia

Fishtail palm

Wine palm

Chrysanthemum

Citrus

Calamondin orange
Locality

P.R.: Lajas*

U.S.: Florida $(86)^{* *}$

Rhodesia and Nyasaland (54)*

Puerto Rico (4)*

U.S.: Florida (86) ${ }^{* *}$

Rhodesia and Nyasaland (54)*

Puerto Rico (79)*

P.R.: Río Piedras, ${ }^{*}$ Isabela, Yauco ***

U.S.: Louisiana (4)

U.S.: Florida $(86)^{* *}$

U.S.: Florida $(86)^{* *}$

P.R.: Naranjito*

Montserrat Is. (67)

U.S.: Louisiana (30)*

U.S.: Florida $(86)^{* *}$ 
Scientific name

C. sinensis (L.) Osbeck

Cocos nucifera $\mathrm{L}$.

Coleus blumei Benth.

Croton spp.

Dioscorea alata L.

Drymaria cordata (L.) Willd.

Emelista tora (L.) Britton and Rose

Gladiolus spp.

Hemerocallis sp.

Impatiens balsamina L.

Inga vera Willd.

Ipomoea batata (L.) Lam.

Lespedeza spp.

Lycopersicon esculentum Mill Manihot utilissima Pohl

Musa paradisiaca L.

$M$. sapienlum $\mathrm{L}$.

Opsiandra maya O. F. Cook

Panicum maximum Jacq.

Paurotis wrightii (Griseb and Wendl.) Britton

Phaseolus vulgaris L.

Phoenix sp.

$P$. reclinata Jacq.

Pinus spp.

Ptychosperma elegans Blume Raphiolepis sp.

Rosa multiflora Thunb.

Roystonea regia O. F. Cook

Sabal palmetto Lodd.

Saccharum officinarum L.

Sansevieria thyrsiflora

Thumb.

Stenotaphrum secundatum

(Walt) Kuntze

Swietenia mahagony Jacq.
Common name

Locality

Sweet orange

Coconut

Coleus

Water yam

Drimaria

Coffeeweed

Gladiolus

Yellow day lily

Balsam

"Guaba"

Sweetpotato

Lespedeza

Tomato

Cassava

Plantain

Banana

Guinea grass

Field beans

Senegal date palm

Pine

Rose

Cuban royal palm

Cabbage palmeto

Sugarcane

Sansevieria

St. Augustine grass

Mahogany
Puerto Rico (4)*

U.S.: Florida (86)**

Jamaica (87)**

P.R.: Villalba*

U.S.: Florida $(86)^{* *}$

P.R.: Naranjito*

P.R.: Río Piedras*

P.R.: Yabucoa*

P.R.: Lajas*

U.S.: Florida (86)*

P.R.: San Juan*

P.R.: Jayuya*

Puerto Rico (4)*

U.S.: Louisiana (4)

Puerto Rico (4)

P.R.: Añasco*

Puerto Rico (4)*

Puerto Rico (4)*

U.S.: Florida $(86)^{* *}$

P.R.: Juana Díaz*

U.S.: Florida $(86)^{* *}$

U.S.: Florida $(86)^{* *}$

U.S.: Florida $(86)^{* *}$

U.S.: Florida (86) **

U.S.: Louisiana (4)*

U.S.: Florida $(86)^{* *}$

U.S.: Florida (86) ${ }^{* *}$

P.R.: Barranquitas*

U.S.: Florida (86) ${ }^{* *}$

U.S.: Florida (86)**

Puerto Rico (4)*

P.R.: Arecibo*

P.R.: Barceloneta*

Puerto Rico (4)* 

JOURNAL OF AGRICULTURE OF UNIVERSITY OF PUERTO RICO

Scientific name

Trifolium repens $\mathrm{L}$.

Valerianoides jamaicense

(L.) Kuntze

Washingonia spp.

Zea mays L.

Zoysia spp.
Common name

Whiteclover

Vervain

Corn

Zoysia
Locality

U.S.: Louisiana (4)

P.R.: Río Piedras**

U.S.: Florida $(86)^{* *}$

Puerto Rico (4)*

U.S.: Florida**

Rotylenchulus borealis Loof and Oostenbrink, 1962

Plum

Netherlands $(48)^{*}$

Malus spp.

Apple

Netherlands (48)*

Fragaria chiloensis Du-

Strawberry

Netherlands $(48) *$ chesne

Solanum tuberosum $\mathrm{L}$.

Potato

Netherlands $(48)^{*}$

Rotylenchulus leiperi (Das, 1960) Loof and Oostenbrink, 1962

Lactuca sativa $\mathrm{L}$.

Lettuce

India: Hyderabad (26)

Rotylenchulus parvus (Williams, 1960) Sher, 1961

Saccharum officinarum L. Sugarcane Mauritius (88)**

Rotylenchulus queirozi (Lordello and Cesnick, 1958) Sher, 1961

Lycopersicon esculentum Tomato Brazil (49)

Mill.

Rotylenchulus reniformis Linford and Oliveira, 1940

Abelmoschus esculentus (L.) Okra

Moench.

Acasia farnesiana (L.)

Willd.

Ageratum conyzoides L.

Amarantus spinosus L.

Ananas sativus Schultes

vars. Smooth Cayenne

Red Spanish

Bull Head

Argyreia nervosa Burm
Casha

Ageratum

"Bledo"

Pineapple

Bojer
Hawaii $(46)^{* *}$

Africa: Gold Coast $(65)^{* *}$

Caja de Muertos Is.*

Hawaii (46)*

Africa: Gold Coast $(65)^{* *}$

P.R.: Manatí, Corozal, Lajas, Vega Alta, Barceloneta, Vega

Baja, Arecibo, Las

Piedras, Juana

Diaz***

Hawaii: $(46)^{* * *}$

Hawaii $(46)^{* *}$ 
Scientific name

Bambos vulgaris Schrad.

Begonia semperflorens Link and Otto

Beloperone guttata

Beta vulgaris L.

B. vulgaris L.

var. cicla $\mathrm{L}$.

Bixa orellana L.

Brassica oleracea L.

var. acephala DC.

B. oleracea L.

var. botrytis $\mathrm{L}$.

$B$. oleracea $\mathrm{L}$.

var. capitata

$B$. pekinensis Rupr.

Buddleia asiatica Lour.

Cactus intortus Mill.

Cajanus indicus Spreng.

Calendula officinalis $\mathrm{L}$.

Callistephus chinensis Cass.

Capsicum anuum $\mathrm{L}$.

Carica papaya $\mathrm{L}$.
Common name

Bamboo

Begonia

Brandegae

Beet

Swiss chard

Annatto

Kale

Cauliflower

Cabbage

Chinese cabbage

Turk's-head

Pigeonpea

Pot marigolid

China-aster

Red pepper

Papaw
Locality

P.R.: Río Piedras*

Hawaii: $(46)^{* *}$

Hawaii $(46)^{* *}$

Hawaii $(46)^{* *}$

U.S.: Louisiana $(16)^{* * *}$

Hawaii $(46)^{* *}$

Hawaii $(46)^{* *}$

Hawaii $(46)^{* *}$

Hawaii $(46)^{* *}$

Hawaii $(46)^{* *}$

Hawaii $(46)^{* *}$

Hawaii $(46)^{* *}$

Caja de Muertos Is.*

Caja de Muertos Is.*

Hawaii $(46)^{* *}$

Hawaii $(46)^{* *}$

Hawaii $(46)^{* *}$

P.R.: Naranjito*

P.R.: Isabela, Hatillo*

Caja de Muertos Is.*

Hawaii (46) **

U.S.: Florida (yr) **

Australia: Queensland (24)*

Asiatic penny- Hawaii (46)*

wort

"Flor de pito" P.R.: Río Piedras**

"Lechecilla"

P.R.: Río Piedras**

"Paragüita"

Chickpea

Watermelon

Pummelo
Caja de Muertos Is.*

Africa: Gold Coast (28)*

P.R.: Río Piedras*

U.S.: Louisiana (18)**

East Pakistan (83)* 
Scientific name

C. limonia Osbeck

C. maxima (Burm.) Merill

Citrus sinensis (L.) Osbeck

Coccoloba uvifera (L.) Jacq.

Cocos nucifera $\mathrm{L}$.

Coleus blumei Benth.

Commelina difusa Burm.

Crepis japonica (L.) Benth

Crotalaria sp.

C. anagyroides H.B.K.

C. juncea $\mathrm{L}$.

C. striata DC.

C. spectabilis Roth.

Croton humilis L.

Cucumis melo $\mathrm{L}$.

C. sativus $\mathrm{L}$.

Cucurbita maxima Duch.

Cucurbita pepo

Cucurbita pepo var. melo pepo

Cynara scolymus L.

Cynodon dactylon (L.) Pers.

Daucus carota L.

var. sativa DC.
Common name

Lemon

Grapefruit

Sweet orange

Sea-grape

Coconut

Coleus

Dayflower

Asiatic hawks beard

Crotalaria

Ornamental crotalaria

"Matraca"

Pepper bush

Muskmelon

Cucumber

Gourd

Pumpkin

Scallop

Artichoke

Bermuda grass

Carrot
Locality

Africa: Gold Coast $(65)^{* *}$

P.R.: Río Piedras*

P.R.: Río Piedras, Bayamón, Trujillo Alto, Isabela*

Hawaii $(46)^{* *}$

P.R.: Carolina*

Africa: Guam (69)*

Hawaii $(46)^{* *}$

P.R.: Luquillo*

Hawaii $(46)^{*}$

P.R.: Manatí*

Africa: Gold Coast (28)*

P.R.: Río Piedras**

Africa: Gold Coast (28)*

Africa: Gold Coast $(66)^{* *}$

Africa: Gold Coast $(66)^{*}$

Hawaii $(46)^{* *}$

Caja de Muertos Is.*

P.R.: Santa Isabel*

U.S. Louisiana (18)**

P.R.: Corozal, Lajas*

Hawaii: $(46)^{* *}$

U.S.: Alabama (59) *

Louisiana (18)**

Pakistan: (88)**

U.S.: Louisiana $(18)^{* *}$

U.S.: Louisiana (18)**

Hawaii $(46)^{* *}$

Hawaii (85)**

Hawaii $(46)^{* *}$

Africa : Gold Coast $(66)^{* *}$ 
Scientific name

Desmodium tortuosum (Sw.) Beggarweed DC.

Dieffenbachia seguine (Jacq.) Schott

Digitaria sanguinalis Scop.

Dolichos lablab L.

Dracaena fragans Ker-gawl

D. deremensis

var. warnekii Engler.

D. sanderiana Hort.

Echeveria sp.

Elaeodendrum xylocarpum

(Vent.) DC.

Eleusine indica (L.) Gaertn. Goosegrass

Emilia sonchifolia (L.) DC. "Yerba social-

Emelista tora (L.) Britton Coffeeweed and Rose

Erechtites valerianifolia (L.) Fireweed Raf.

Erigeron albidus (Willd.) Horseweed Gray

Eugenia melaccensis L.

Euphorbia hirta L.

E. hypericifolia L.

E. pulcherrima Willd.

Fleurya aestuans (L.) Gaud.

Fragaria chiloensis Duchesne

Glycine max Merr.

Gossypium spp. ista"

Dumb cane

Crabgrass

Hyacinth bean

Indian palm

Dracena

Sanders dracena

Marbletree

Mountain apple

Garden spurge

Graceful spurge

Poinsettia

West Indian needle

Strawberry

Cotton
P.R.: Corozal

Africa: Gold Coast $(66)^{* *}$

\section{Locality}

U.S.: Florida (2S)**

P.R.: Naguabo*

P.R.: Isabela*

Pakistan (83)**

P.R.: Arecibo*

P.R.: Río Piedras, Arecibo*

P.R.: Arecibo*

Hawaii $(46)^{* *}$

Caja de Muertos Is.*

P.R.: Isabela, Río Piedras***

Hawaii $(46)^{*}$

P.R.: Isabela, Río

Piedras***

Hawaii (46)*

U.S.: Florida (77)*

Hawaii $(46)^{*}$

Hawaii (46)*

Hawaii $(46)^{* *}$

Hawaii $(46)^{*}$

Hawaii $(46)^{*}$

Hawaii $(46)^{* *}$

P.R.: Río Piedras**

Africa: Gold Coast

$(65)^{* *}$

U.S.: Georgia (75)**

United States (75)* 
Scientific name

Hedychium coronarium Koenig

Holchus sorghum L.

H. sorghum $\mathrm{L}$.

var. caudalus Bailey

Hibiscus rosa-sinensis $\mathrm{L}$.

Hyptis capitata Jacq.

Impatiens balsamina $\mathrm{L}$.

Indigofera suffruticosa Mill. Inga laurina (Sw.) Willd. Ipomoea batatas (L.) Lam.

I. tiliacea (Willd.) Choisy

I. tuberosa $\mathrm{L}$.

Ixora coccinea L.

Jacquemontia tamnifolia

Griseb.

Kalanchoe sp.

Lactuca sativa L.

Lamairocereus hystrix

Lantana aculeata $\mathrm{L}$.

Lathurus hirsutus

Leonotis nepetaefolis (L.) R. Br.

Lepidium virginicum $\mathrm{L}$.

Laucaena glauca Benth.

Lycopersicon esculentum Mill.
Common name

White ginger

Sorghum

Feterita

Chinese hibiscus

Wild hops

Balsam

Wild indigo

Pomsock

Sweetpotato
Locality

Hawaii (46)*

Africa: Guam (69) **

Hawaii $(46)^{* *}$

P.R.: Río Piedras*

P.R.: Río Grande*

P.R.: San Juan*

Hawaii (46)**

Hawaii $(46)^{* *}$

P.R.: Jayuya*

P.R.: Barranquitas, Corozal, Yauco, Aguadilla*

Africa: Gold Coast $(65)^{* *}$

U.S.: Louisiana (55) $* * *$

Wild morning- P.R.: Río Piedras* glory

Wooden rose

Hawaii $(46)^{* *}$

Burning love

P.R.: Santurce*

U.S.: Georgia (77)**

Hawaii $(46)^{* *}$

Lettuce

Spanish dildo

Pink sage

Singletaru peas

Lion's ear

P.R.: Las Piedras*

Hawaii $(46)^{* *}$

Caja de Muertos 1s.*

Caja de Muertos Is.*

U.S.: Louisiana $(18)^{* *}$

P.R.: Isabela*

Peppergrass

"Acacia"

P.R.: Barceloneta*

U.S.: Florida (7y)*

Tomato
P.R.: Isabela, Corozal, San Germán, Río Piedras, ${ }^{* * *}$ Hawaii

$(46)$, ,* Pakistan (83), ${ }^{* *}$ Africa: Gold Coast (65), ${ }^{* *}$ Australia (24), United States (77), ${ }^{*}$ U.S.: 
Scientific name

Malpighia infestissima

(A. Juss.) Rich.

M. punicifolia L.

Mangifera indica $\mathrm{L}$.

Manihot utilissima Pohl

Mimosa pudica $\mathrm{L}$.

Mirabilis jalapa L.

Murraea exotica L.

Musa paradisiaca L.

M. sapientum L.

Nicotiana tabacum $\mathbf{L}$.

Panicum maximum Jacq.

Parthenium hysterophorus

L.

Passiflora edulis Sims.

$P$. seemanni Griseb

Persea americana Milld.

Pepo moschata (Duch.) Brit- Pumpkin ton

Phaseolus lathyroides I.
Tobacco

Common name

Cowhage cherry

West Indian cherry

Mango

Cassava

Sensitive plant

Four-o'clock

Orange jessamine

Plantain

Banana

Guinea grass

Mugwort

Waterlemon fruit

Passionflower

Avocado

Wild pea-bean
Locality

Louisiana (4), ${ }^{* *}$ Florida (77)*

P.R.: Isabela*

P.R.: Isabela, Dorado*

U.S.: Florida (86)*

Africa: Gold Coast $(65)^{* *}$

P.R.: Río Piedras, Manati, *** Río Grande, Naguabo***

P.R.: Río Piedras*

Hawaii $(46)^{* *}$

P.R.: Río Grande, Corozal, Luquillo, Río Piedras, Isabela, Naranjito, San Juan, Arecibo*

P.R.: Lares, Castañer, Río Grande, Río Piedras*

P.R.: Río Piedras, Orocovis, Manatí, Aguas Buenas, Barceloneta, Gurabo***

Africa: Gold Coast $(65)^{* *}$

United States: $(78) *$

P.R.: Juana Diaz*

P.R.: Isabela*

P.R.: Isabela*

Hawaii $(46)^{* *}$

Africa: Gold Coast

$(65)^{* *}$

P.R.: Isabela*

Hawaii $(46)^{* *}$

Hawaii $(46)^{* *}$ 
Scientific name

Phaseolus limensis var. limenaus

Phaseolus vulgaris var. humilis

P. limensis Macf.

P. lunatus L.

$P$. vulgaris $\mathrm{L}$.

$P$. vulgaris L.

var. humilis

Philodendron duvium Hort.

$P$. oxycordium

$P$. pertusum Kunth and Bche.

Phlox drummondii Hook

Pisum sativum $\mathrm{L}$.

Poinciana pulcherrima L.

Polyscias guilfoylei (Bull.) Bailey

Portulaca oleracea L.

Pothos aureus Lindl. and André

Prosopis chilensis (Molina) Stuntz

Psidium guajava $\mathrm{L}$.

Pueraria thunbergiana Benth.

Quamoclit coccinea Moench.

Q. pinnata (Desr.) Boj.

Raphanus sativus L.

Richardia scabra

Saccharum officinarum L.
Common name

Bush lima bean

Bush bean

Bush lima bean

Civetbean

Field beans

Bean

Philodendron

do.

do.

Garden pea

Barbados flowerfence

Nothopanax

Purslane

Yellow tree lover

"Algarroba"

Guava

Tropical kudzu

Star ipomoea

Cypress vine

Radish

False ipecac

Sugarcane
Locality

U.S.: Louisiana (18)**

U.S. Louisiana $(19)^{* *}$

Hawaii: $(46)^{* *}$

U.S.: Louisiana $(16)^{* * *}$

U.S.: Louisiana (4)*

Africa: Gold Coast

(28)*

P.R.: Isabela, Barranquitas*

Hawaii $(46)^{* *}$

Africa: Gold Coast $(65)^{* *}$

U.S.: Louisiana $(16)^{* * *}$

P.R.: Vega Alta*

P.R.: Vega Alta*

P.R.: Vega Alta*

Hawaii $(46)^{* *}$

Hawaii $(46)^{* *}$

Africa: Gold Coast

$(65)^{* *}$

P.R.: Aguadilla*

Hawaii $(46)^{* *}$

P.R.: Isabela, Río Piedras***

Hawaii $(46)^{* * *}$

P.R.: Arecibo, Vega Baja, Vega Alta*

Hawaii $(46)^{* * *}$

P.R.: Isabela*

Africa: Gold Coast

(28)*

P.R.: Isabela*

P.R.: Río Piedras*

P.R.: Fajardo*

Hawaii (46)*

P.R. Isabela, Ponce, 
Scientific name

Schinus terebinthifolius

Raddi

Sida carpinifolia L.

Soja max (L.) Piper

Solanum melongena $\mathrm{L}$.

S. nigrum L.

S. quitoensis Lam.

S. tuberosum L.

Sonchus oleraceus L.

Stachys arvensis $\mathrm{L}$.

Stenotaphrum secundatum

(Walt.) Kuntze

Stizolobium deeringianum

Bort.

Swietenia mahagony Jacq.

Synedrella nodiflora Gaertn.

Tagetes erecta $\mathrm{L}$.

T. patula L.

Trifolium spp.

T. incarnatum

T. repens

Taxus spp.

Urena lobata $\mathrm{L}$.

Vanilla fragans (Salisb.)

Ames

Vernonia cinerea (L.) Less

Vicia faba $\mathrm{L}$.

Vicia villosa Roth.

Vigna sinensis Endl.
Common name

\section{Locality}

Lajas, Loiza, Manatí, Río Piedras, Aguadilla*

Christmas-berry Hawaii $(46)^{* * *}$ tree

Wireweed

Soybean

Eggplant

P.R.: Isabela*

Africa: Gold Coast $(65)^{*}$

P.R.: Corozal, Lajas*

Hawaii $(46)^{* *}$

Africa: Gold Coast**

Black nightshade Hawaii $(46)^{*}$

"Naranjilla" P.R.: Corozal*

Potato Hawaii (46)**

Annual sowthis- Hawaii (46)* tle

Staggerweed Hawaii $(46)^{* *}$

St. Augustine Hawaii (85)* grass

Velvetbean

Mahogany

Africa: Gold Coast (28)*

P.R.: Yauco, Quebradillas*

Africa: Gold Coast $(65) * *$

African marigold Hawaii (46)**

French marigold Hawaii $(46)^{* *}$

Clover

Crimsom clover

Whiteclover

Yew

Bur

U.S.: Louisiana (16)

U.S.: Louisiana $(16) * * *$

U.S.: Louisiana $(16)^{* * *}$

United States (78)

P.R.: Manati*

Vanilla

P.R.: Río Piedras*

Ironweed

Hawaii $(46)^{*}$

Broadbean

Hairyvetch

Hawaii (44)

Pakistan (82) **

Africa: Gold Coast

(28)*

U.S.: Louisiana $(18)^{* *}$

Cowpea 
Scientific name

Wedelia trilobata (L.)

Hitchc.

Xanthium sp.

Xanthosoma saggitaefolium

(L.) Schott

Zea mays $\mathrm{L}$.

Zinnia elegans Jacq.
Locality

Hawaii $(46)^{* * *}$

Africa: Gold Coast

$(65)^{* *}$

"Manzanilla"

Cocklebur

Tanier

U.S.: Florida (23) $* *$

P.R.: Isabela*

Corn

P.R.: Lajas, San Germán, Río Piedras, Isabela*

Hawaii (46) **

Africa: Gold Coast $(66)^{*}$

Rhodesia and Nyasaland $(54)^{*}$

Hawaii $(46)^{* *}$

\section{DISCUSSION}

The reniform nematode, Rotylenchulus Linford and Oliveira, 1940, of which five species have been described, is widely distributed. it has been reported from 15 countries including 5 States of the southern part of the United States. In Puerto Rico it has been found in 40 localities. The populations are generally higher in loamy soils rich in organic matter. In pineapple fields it is numerous in sandy loams and in clay soils. In the pigeonpea, which has been found to be one of the best hosts, its populations are high, even in very dry sandy and saline soils and in heavy, moist clays. It was also found in coffee, plantain, and coleus at about 3,000 feet above sea level, and in heavy soils rich in organic matter. Temperature, humidity, and $\mathrm{pH}$ of the soil do not seem to affect its abundance and distribution in an appreciable way, as shown by the findings of high populations under varied climatic conditions.

Probably more than one species are represented here as evidenced by the observations of morphological differences and host-parasite relationships. As an example, sugarcane, which is normally a host under field conditions, was not attacked in greenhouse inoculation tests by populations obtained from about pigeonpea roots. The same situation is true for other cultures in relation to several other crops.

Different degrees of susceptibility have been observed among the plants included in the previous list, ranging from very susceptible plants like 
pigeonpea, Cajanus indicus, in the roots of which the nematode reaches great numbers in a few months, to ornamental crotalaria, Crotalaria anagyroides, where only a limited number of females can grow and reproduce.

Two hundred and one plant species are recorded as hosts in this paper. Eighty-nine of them are found in Puerto Rico. Sixty-four new host plants are reported here from Puerto Rico and Caja de Muertos Island; 15 for Rotylenchulus spp. and 74 for $R$. reniformis. Some of them were found to be nonhosts when studied under controlled conditions, but in most cases the host-parasite relationships have been corroborated in greenhouse trials.

Most of these plants are usually attacked by mixed populations of several other parasitic nematode species, but in some of them like pineapple, Ananas sativus; sweetpotato, Ipomoea balatas; pigeonpea, Cajanus indicus; tomato, Lycopersicon esculentum; and tobacco, Nicotiana tabacum, the reniform nematode predominates even over conmon abundant species like the root knot nematode. In these crops the nematode is usually associated with crop damage. In other crops like sugarcane, Saccharum offcinarum, corn, Zea mays, and others, only few specimens are usually encountered.

\section{SUMMARY}

The reniform nematode which comprises five described and several undescribed species has been recognized as a dangerous plant parasite. It is undoubtedly one of the most common nematode types in our soils and its populations are usually very high. It has been found associated with most of our agricultural crops including pineapple, coffee, pigeonpea, tobacco, sugarcane, ornamentals, and vegetables.

Increasing interest in the study of this parasite has suggested the existence of several other species which still remain undescribed. In l'uerto Rico, it is now evident that several species are present. This statement is based on differences observed in relation to morphological and pathogenic characteristics among different populations.

A list of 201 different host plants from 1ij countries, including Puerto Rico and Caja de Muertos, an adjacent Island south of Puerto Rico, is given. Most of them are the result of field observations, but in many cases the susceptibility of the host has been corroborated on greenhouse inoculation trials. Fighty-nine host plants were found in P'uerto Rico, 1is of which are new hosts to Rolylenchulus spp., and 74 to $R$. reniformis. Differences in degrees of susceptibility have been recognized, pigeonpea being the most susceptible, and ornamental crotalaria only a carrier.

In Puerto Rico, the nematode has been located in 40 localities in some of which several plants have been found to be hosts. Humidity, clevation, 
temperature, and soil $\mathrm{pH}$ do not seem to be limiting factors in relation to the occurrence and distribution of the nematode. It occurs more in loamic soils but clay or sandy soils with little organic matter harbor large numbers if a suitable host plant is present.

A general list of publications regarding this nematode citing 89 papers is also included.

\section{RESUMEN}

El nemátodo reniforme Rotylenchulus Linford y Oliveira 1940 comprende cinco especies descritas y otras aún sin describir. Es sin duda uno de los más comunes en nuestros suelos; ocurre en grandes números y se considera como un parásito dañino de muchas plantas. La mayor parte de las cosechas comerciales de Puerto Rico, tales como la piña, el tabaco, la caña, las plantas ornamentales y las hortalizas sufren de sus ataques.

Anteriormente se creía que había una sola especie, Rotylenchulus reniformis, pero debido al mayor interés en este estudio, se ha llegado a la conclusión de que existen varias otras especies aún sin describir. En Puerto Rico es evidente que tenemos varias especies de este nemátodo, porque se han observado diferencias morfológicas, al igual que patogénicas, en distintas especies de este organismo.

El presente trabajo incluye 201 plantas hospedadoras en 1i) distintos países incluyendo a Puerto Rico y Caja de Muertos, que es una pequeña isla al sur de Puerto Rico.

las observaciones, en su mayoría, se han hecho en el campo, pero cu otras ocasiones ha sido en pruebas en invernaderos donde se ha corroborado la susceptibilidad de las plantas al atacue de este nemátodo.

De las 89 plantas informadas de Puerto Rico, 15 se determinaron por primera ve\% que son hospedadoras del Rotylenchulus spp. y $74 \mathrm{del} R$. reniformis. Las restantes ya habían sido informadas en trabajos anteriores. La susceptibilidad de estas plantas a los efectos del nemátodo varía en grado, desde el gandul que es la más afectada, hasta el pitillo ornamental en cuyas raíces suelen desarrollarse pocas hembras que producen un número muy limitado de huevos.

En Puerto Rico, el nemátodo se encontró en 40 localidades, en algunas de las cuales se observó que un gran número de plantas estaban afectadas por este organismo. Tal parece, que ni la humedad, la temperatura, el pH y la elevación del terreno sean factores que restrinjan en modo alguno la presencia y distribución de este nemátodo.

Se observó, además, que este nemátodo abunda más en los suelos ricos cn materia orgánica, pero aun en acpuellos suelos deficientes en contenido orgánico son numerosas las poblaciones de este organismo si hay buenas plantas hospedadoras. 
También se incluye aquí una lista general que comprende 89 publicaciones relacionadas con el nemátodo reniforme.

\section{LITERATURE CITED}

1. Allen, M. W., The genera Pratylenchus, Radopholus, Pratylcnchcidcs, Rotylcnchulus and Nacoblus; Tylenchulus, Trophotylenchulus, Trophonen;a, Sphacronema, Nematology : Fundamentals and Recent Advances with Emphasis on Plant Parasitic and Soil Forms, Univ. N. C. Press, Chapel Hill, N.C., pp. 181-4, 1960. (Discussion on the taxonomic position of the genus Rotylenclulus.)

2. Allen, M. W., and Maggenti, A. R., Plant nematology in (alifornia: State's crop losses led to first department for research in plant nematology to be established by Experiment Stations, Calif. Agr. 13 (9) 2-3, 1959. (Rotylenchulus reniformis is reported along with other parasitic species from ornamentals in California.)

3. Anderson, E. J., Comparison of initial kills and subsequent increase of nematode populations following soil fumigation, (abs.) Phylopath. 46 (11) 634, 1956. (Population increases of Rotylenchulus reniformis were observed in pineapple roots after fumigation with D-D, EDB, and Nemagon in Hawaii.)

4. Anonymous, Distribution of Plant Parasitic Nematodes in the South, Southern Co-op. Ser. B. $7442-3,1960$. (Rotylenchulus spp. and $R$. reniformis are reported as attacking several hosts in the Southern States and Puerto Rico.)

5. - Biennial Report 1956-58, Hawaii Agr. Expt. Sta., Univ. Hawaii, pp. 47 and 55-6, 1958. (Growth and yield of papaya increased after application of nematocides for controlling Rolylenchulus reniformis in Hawaii.)

6. Ayala, A., An Analysis of the quantitative and qualitative composition of the nematode populations in pineapple fields in Puerto Rico, J. Agr. Univ. P.R. 45 (4) 265-99, 1961. (Rotylenchulus reniformis was found to be the most common and numerous among 23 genera of known and suspected plant parasitic nematodes in pineapple fields in Puerto Rico.)

7. - - Parasitism of bacterial nodules by the reniform nematode, J. Agr. Univ. P.R. 46 (1) 67-9, 1962. (Bacterial nodules attached to pigeonpea roots were found to be atlacked by an undescribed species of the reniform nematode.)

8. - - Pathogenicity of the reniform nematode on various hosts, $J$. Agr. Univ. P.R. 46 (2) 73-82, 1962. (The behavior of a population of Rolylenchulus spp. Wats studied on seven liosts. All but sugarcane were attacked by the nematode.)

9. - - , Occurrence of the nematode Meloidogyne javanica on pigeonpen roots in Puerto Rico, J. Agr. Univ. P.R. 46 (2) 154-6, 1962. (Rotylenchulus reniformis was mentioned among four parasitic species attacking pigeonpea in Puerto Rico.)

10. - - Greenhouse tests with nematocides for control of nematodes attacking tomato (Lycopersicon esculenlum var. Rutgers) in Puerto Rico, $J$. Agr. Univ. P.R. 46 (4) 319-27, 1962. (Rotylenchulus reniformis was controlled with soil treatments with D.D., EDB, Dorlone, Nemagon, Telone, and Fumazone.)

11. Ayala, A., and Román, J., Distribution and host range of the burrowing nematode in Puerto Rican soils, J. Agr. Univ. P.R. 47 (1) 28-37, 1963. (Rotylenchulus reniformis was found widely distributed, on ornamental roots, in Puerto Rico.)

12. Ayala, A., Román, J., and Gandía, H., Effect of soil fumigation used in the control of pineapple nematodes in Puerto Rico, J. Agr. Fniv. P.R. 47 (2) 76-90, 1963. (Rotylenchulus reniformis was one of the must common species of nematodes found on experimental plots of pineapple.)

13. Baker, A. D., (hecklists of the Nematode Superfamilies Dorylamoidea, Rhal). 
ditoidea, Tylenchoidea, and Aphelenchoidea, E. J. Brill, Leiden, Holland, pp. 157, 1962. (Includes Rotylenchulus in the subfamily Pratylenchinae.)

14. Birchtield, W., Host-parasite studies on reniform nematode on cotton, (abs.) Phylopath. 62 (1) 4, 1962. (Death of roots is reported caused by necrosis and partial dissolution of cells. The reniform nematode was observed feeding in phloem.)

15. - Host-parasite relations of Rotylenchulus reniformis on Gossypium hirsutum, Phylopath. 62 (9) 862-5, 1962. (Parasitism of Rotylenchulus reniformis on cotton is demonstrated. Life cycle and host relationships are discussed.)

16. Birchfield, W., and Brister, L. R., New hosts and nonhosts of reniform nematode, Plant Lis. Rplr. 46 (9) 683-5, 1962. (Forty-three agronomic plants were tested for their reaction to Rotylenchulus reniformis. Eleven nonhosts were discovered which were adaptive to growing in Louisiana, where this organism is a serious pest. Six new hosts were reported.)

17. Birchfield, W., and Brister, L. R., New hosts and crop plants resistant to the reniform nematode, (abs.) Phytopath. 62 (8) 725, 1962. (Six new hosts and 12 inmune plants are reported.)

18. Birchfield, W., and Jones, J. E., Distribution of the reniform nematodes in relation to crop failure of cotton in Louisiana, Plant Dis. Rptr. 45 (9) 671-3, 1961. (Rolylenchulus reniformis was found to be widely distributed in cotton in Louisiana causing yield reduction of $40-60$ percent.)

19. Carvalho, J. C., Rotylenchus elisensis nova espécie associada com raízes de soja, Rev. Inst. Adolfo Lutz 17 (1) 43-6, 1958. (A new species of Rotylenchus was described; this was later transferred to Helicolylenchus and eventually synonymised with Rolylenchulus reniformis by Sher.)

20. - Helicotylenchus clisensis n. comb. (Nematoda: Tylenchida) Arch. Inst. Biol., São Paulo, $2645-8$, 1959. (Rolylenchus elisensis was relocalized in the genus Helicolylenchus.)

21. Chitwood, B. G., and Birchifield, W., Nematodes-Their kinds and Characteris. ties, State Plant Board of Florida 13. 9, 2 16-17, 1956. (Rotylenchulus reniformis is reported as attacking ornamentals in Florida, and various field crops, suclı as cotton, in other parts of the United States.)

22. Chitwood, B. G., and Chitwood, M. B., An Introduction to Nematology, Monumental Printing Co., Baltimore, Md., rev. ed., pp. 1-213, 1950. (The genus Rotylenchulus was placed with Nacobbus in a new subfamily, Nacobbinae.)

23. Christie, J. R., Plant Nematodes, their Bionomics and Control, H. \& W. B. Drew Co., Jacksonville, Fla., pp. 142-3, 1959. (A description of Rotylenchulus reniformis is followed by a summary of previous reports. Beggarweed and cocklebur are listed as hosts in Florida. Rotylenchulus spp. was reported from roots of cotton.)

24. Colbran, R. C., Chemical control of nematodes in South Queensland pineapple fields, Queensland Agr. J. 17 (3) 165-73, 1960. (Rotylenchulus reniformis was found attacking tomatoes and papaws, but not pineapple.)

25. Collins, I. J., The Pineapple, Botany, Cultivation and Utilization, Intersci. Publ. Inc., New York, N.Y., pp. 205-7, 1960. (Rolylenchulus reniformis is mentioned as occurring everywhere pineapple is planted.)

26. Das, V. M., Studies on the nematode parasites of plants in Hyderabad Andhra Pradesh, India, Z. Parasitenk 19 553-605, 1960. (Leiperolylenchus leiperi was described from roots of lettuce from Hyderabad, India. This nematode was pluced in Rolylenchulus by Loof and Oostenbrink.) 
27. Doolittle, S. P., Tomato Diseases, USDA Farmer's B. 1934 52-5, 1948. (Rotylenchulus spp. is included among the parasitic nematodes that affect tomatoes.)

28. Eduards, E. E., Studies on resistance to the root-knot nematode of the genera Meloidogyne Goeldi, 1887, Proc. Helminthol. Soc Wash. 23 (2) 112-8, 1956. (Rotylenchulus reniformis was found associated with 8 different plant species during a study on the resistance of the root-knot nematode in the Gold Coast. Morphological differences from the original descriptions were observed.)

29. Fielding, M. J., Nematodes in Plant Diseases, Annu. Rev. Microbiol. 13 239-51, 1959. (Wilt damage was more severe in susceptible cotton, if grown in the presence of Rotylenchulus reniformis in Louisiana.)

30. Fielding, M. J., and Hollis, J. P. Occurrence of plant parasitic nematodes in Louisiana soils, Plant Dis. Rptr. 40 (5) 403-5, 1956. (Rotylenchulus reniformis is reported as attacking cotton and Rotylenchulus spp. from citrus, in Luuisiana.)

31. Goodey, J. B., Soil and Freshwater Nematodes, John Wiley \& Sons Inc., New York, N.Y., 1963. (A description of Rotylenchulus under the Pratylenchinae (Hoplolaimidae) is given.)

32. Goodey, J. B., and Franklin, M. T., The Nematode Parasites of Plants Catalogued under their Hosts, Commonwealth Agr. Bureaux, England, pp. 1-10, 1956. (A list of several previous reports of the reniform nematode from different places is given.)

33. Coodey, J. B., Franklin, M. T., and Hopper, D. J., Supplement to the Nematode Parasites of Plants Catalogued under their Hosts, 1955-58, Commonwealth Agr. Bureaux, England, pp. 1-66, 1059. (Several other reports of the reniform nematode after 1956 are included.)

34. Goodey, T., Soil and Freshwater Nematodes: A Monograpl, John Wiley \& Sons Inc., New York, N.Y., pp. 119-30, 1951. (A description of Rolylenchulus reniformis is given and the genus Rotylenchulus is included under the subfamily Pratylenchinae.)

35. Hopper, B. E., and Cairns, E. J., Taxonomic Keys to Plant, Soil and Aquatic Nematodes, Ala. Polytech. Inst., Auburn, Ala., (mimeo.) p. 16, 1959. (The genus Rotylenchulus is included under the subfamily Nacobbinae.)

36. Hung, Y. P., Some Important Plant Nematodes in Taiwan, Kaohsiong District Agricultural Improvement Station, Pingtung, Taiwan, p. 13, 1961.

37. Ichinohe, M., Bibliography on plyytonematology, Japan Plant Protection Association, Tokyo, Japan, pp. 1-98, 1961. (A list of 12 articles relating to the reniform nematode, Rolylenchulus reniformis, is given.)

39. Jones, F. G. W., An Introduction to Plant Nematology, Plant Nem. Tech. B. 7, pp. 7-31, 1959.

39. Jones, J. L., and Newson, L. J)., liffect of Soil Fumigation for Control of the Reniform Nematode, Rolylenchulus reniformis on Yield and Lint Characters of Upland Cotton, Proc. Assoc. South. Agr. Workers 53d. Annual Convention, pp. 64-5, 1956. (The results of severul experiments for the control of Rolylenchulus reniformis and its effect on yield and lint characters of upland cottons are discussed.)

40. Jones, J. J., Newson, L. D., and Finley, 1\%. 1\%., liffect of the reniform nematode on yield, plant characters, and fiber properties of upland cotton, Agron. $J$. 51 (6) 353-6, 1959. (Rotylenchulus reniformis reproduced abundantly on cotton and caused serious injuries to all varieties of cotton tested causing reduction in yield of lint, delay in maturity, and reduction in the size of ball.)

41. Lange, A. H., Reacción del papayo a la fumigación de suelos, Agroquimia 3 (2) 
1-3, 1959. (Growth and yicld of papaya are greatly improved with the application of nematocides for the control of Rolylenchulus reniformis.)

42. Jatnge, A. H., and Holtzmann, O. V., Papaya responds to soil fumigation, Hawaii Farm Sci. 6 6-7, 1958. (Growth and yield of papaya are greatly improved with the application of nematueides for the control of Rotylenchulus reniformis.)

43. Linford, M. B., The feeding of nematodes before and during their entry into roots, (abs.) Phylopath. 31 (9) 862, 1941. (Heterodera marioni (= Meloidogyne sp.), Rotylenchulus, Pratylenchus, Rotylenchus, and Paratylenchus were included.)

44. Isinford, M. B., and Oliveira, J. M., Rolylenchulus reniformis nov. gen. nov. sp., a nematode parasite of roots, Proc. Hclminthol. Soc. Wash. 7 (1) 35-42, 1940. (Rotylenchulus reniformis is described as attacking soybean roots in Hawaii.)

45. Linford, M. B., Oliveira, J. M., and Yap, F., The reniform nematode as a root parasite, (abs.) Phylopalh. 30 (1) 15, 1940.

46. Linford, M. B., and Yap, F., Some host plants of the reniform nematode in Hawaii, Proc. Helminlhol. Soc. Wash. 7 (1) $42-4$, 1940. (Sixty-five plants belonging to thirty families are given as hosts of Rolylenchulus reniformis.)

47. Loof, P. A. A., and Oostenbrink, M., Synopsis of the (ienus Rotylenchulus VIth International Nematology Symposium, abs. of the papers, Gand (Belgique), 24-2s juillet, p. 57, 1961. (A discussion of the reniform nematode including the 3 described species is presented and a new undescribed species is suggested to occur in the Netherlands.)

48. Loof, P. A. A., and Oostenbrink, M., Rotylenchulus borealis n. sp. with a key to the species of Rolylenchulus, Nemalologica 7 (1) 83-90, 1962. (A new species is described from grasses in the Netherlands. A short discussion of species and a key are given. Immature females of this species were also collected from soil around plum and apple orchards, and in a strawberry and a potato ficld.)

49. Lordello, L. (i. L., and Cesnik, R., Alguns nematódeos do tomateiro, Rev. Brazil Biol. 18 (2) 159-65, 1058. (A genus and species, Spirotylenrhus qucirozi, was described from tomato in Brazil and later combined into Rolylenchulus queirozi, by Sher.)

50. Lownsbery, B. F., and Thomason, I. J., Progress in nematology related to loorticulture, Proc. Amer. Soc. Hort. Sci. 74 730-46, 1959. (The reniform nematode is mentioned as an exposed endoparasite.)

51. Luc, M., and IIoestra, H., Les nematodes phytoparasites des sols de cocoteraje du Togo, Agron. Trop. (Paris) 15 (5) 497-512, 1960. (Rotylenchulus reniformis is reported as one of the parasitic nematodes attacking coconut palms in Togo, (ihana.)

52. Maggenti, A. R., and Allen, M. W., Nematode structure and life, wide range of life habits requires combination of characters for identification of parasites classified among nematodes, Calif. Agr. 13 (9) 5-7, 1959. (Rotylenehulus reniformis is included along with the citrus nematode among a debatable group of endoparasitic nematodes.)

53. Mai, W. F., and Lyon, H. H., Pictorial Key to Genera of Plant Paratsitic Nematodes, Art Craft of Ithaca, Inc., N.Y., p. 16, 1960. (1)escriptions and illustrations of Linford and Oliveira are given as well as a short list of the most important hosts.)

54. Martin, G. C., Plant and soil nematodes of the Federation of Rhodesia and Nyasaland. (Preliminary investigations. Nematodes catalogued under hosts or associated plants.) J. Rhod. Agr. 62 346-51, 1955. (Rotylenchulus spp. was found on Baobad tree, bamboo, and corn from Rhodesia and Nyasaland.)

55. Martin, W. J., The reniform nematode may be a serious pest of the sweetpotato, 
Plant Dis. Rptr. 44 (3) 216, 1060. (Great reduction in yield was observed when Rotylenchulus reniformis was inoculated to sweetpotato under greenhouse conditions. The nematode was observed also under field conditions.)

56. Martin, W. J., and Birchfield, W., Notes on plant parasitic nematodes in Louisiana, Plant Dis. Rplr. 39 (1) 3-4, 1955. (Rolylenchulus reniformis was found attacking cotton in only one locality in Louisiana.)

57. McBeth, C. W., Nematode pests of perennial crops, Span, London, 2 (1) 10-4, 1959. (Rotylenchulus reniformis is included among the nematodes attacking pineapple wherever it is planted.)

58. Miller, P. R., Plant disease situation in the United States, FAO Plant Protection B. 3 (5) $74-5,1951$. (Rotylenchulus reniformis was found on a cotton field in Louisiana.)

59. Minton, E. B., Smitlı, A. L., and Cairns, li. J., Population build-up, pathogenicity of reniform, root-knot, lance and spiral nematodes on cotton, soybean and tomato in ficld bins, Phylopalh. 60 (8) 576, 1960. (The build-up of populations of Rotylenchulus reniformis was studied in plain cotton, Rutgers tomato, and Lee soybean in field bins previously treated, in Alabama.)

60. Minton, N. A., and Hopper, B. E., The reniform and sting nematodes in Alabama, Plant Dis. Rptr. 43 (1) 47, 1959. (Rotylenchulus reniformis was first reported from Alubama in cotton.)

61. Neal, D. C., Fusarium wilt resistance and fiber properties of some new cotton hybrids and selections, Phylopath. 43 (5) 292, 1953. (Several studies for the selection of resistant varieties of cotton to Fu:arium wilt and Rotylenchulus reniformis attack were conducted.)

62. Neal, D. C., The reniform nematode and its relationship to the incidence of $\mathrm{Fu}$ sarium wilt in cotton at Baton Rouge, La., Phytopalh. 44 (8) 447-50, 1954. (The relationship between Rolylenchulus reniformis and Fusarium wilt was established.)

63. Newson, L. D), and Jones, J. li., Nematocides for control of the reniform nematode-wilt complex of cotton, La. Agr. Expt. Sta. Annu. Rpt. 102, 1954-5. (Report of results on experiments with nematocides for the control of Rotylenchulus reniformis-Fusarium wilt complex in cotton is given.)

64. Oostenbrink, M., Populations of plant parasitic nematodes in meadows, VIth International Nematology Symposium, abs. of papers, Gand (Belgique) 2t-28 juillet, p. 77, 1961. (Rolylenchulus spp. Was included among several other species known and suspected to be noxious to some grasses and whiteclover in the Netherlands meadows.)

65. Penenek, F. C., The reniform nematode in the Gold Coast, Nemalologica 1 (4) 305-10, 1956. (Several hosts are reported from the Gold Coast, some of which are new records to Rotylenchulus reniformis.)

66. - - The reniform nematode in the (iold Coast, Nature 177489 , 1956. (Highteen different hosts are reported for Rolylenchulus reniformis in the (iold Coast.)

67. Pennock, W., Report on a Trip to Montserrat, $A$ gr. Expt. Sta. Univ. P.R. Misc. Publ. 27, (app.) pp. 16-9, 1959. (Rotylenchulus spp. was identified by (i. Steiner from almost all citrus samples examined from the Island of Montserrat.)

68. Román, J., Control of nematodes attacking sugarcane, J. Agr. Univ. P.R. 45 (3) 194-5, 1961. (Rotylenchulus spp. was included among a list of nematodes associated with sugarcane in Puerto Rico.)

69. Reinking, O. A., and Radewald, J. D., Cadang-cadang disease of coconuts in (ilum may be caused by soil-bore plant virus spread by dagger nematodes (Xiphinema sp.), I'lant Dis. Rptr. 45 (6) $411-2,1961$. (Rotylenchulus reniformis 
was found among several other species associated with cadang-cadang disease of coconuts in Guam.)

70. Sasser, J. N., Vargas-González, O. F., and Martin, A., New findings of plantparasitic nematodes in Peru, Plant Dis. Rptr. 46 (3) 171, 1962. (Large numbers of Rotylenchulus reniformis were recovered from rhizospheres of cultivated cotton, orange, banana, cocoa and tobaceo plants from Peru.)

71. Sher, S. A., Nematodes on ornamentals: Root-knot, root-lesion and more specialized or exotic forms may acute injuries in nursery, greenhouse and garden, Calif. Agr. 13 (9) 21-2, 1959. (Rotylenchulus reniformis was classified as exotic parasite found only in nurseries in California.)

72. - Revision of Hoplolaiminae (Nematoda): I (lassification of nominal genera and nominal species, Nematologica 6 (2) 15E-69, 1961. (Srirolylenchus qucirozi and Helicolylenchus parvus were combined under Rolylenchulus creating $R$. parvus and R. queirozi. Helicolylenchus elisensis synonymized with R. reniformis.)

73. S'Jacob, J. J., Hoplotylus femina, n.g., n.sp. (Pratylenchinae: Tylenchida) associated with ornamental trees, Nemalologira $4317-21,1959$. (Rotylenchulus is included among six genera belonging to the Pratylenchinae.)

74. Skarbilovich, T. S., Sveklowinaya Nematoda i mery borjby s nei, Trud. osesoyuz, Gelmint. 8 5-214, 1960. (Rotylenchulus and Tylenchulus was placed in the Tylenchulinae (Heteroderidae).)

75. Smith, A. L., Jistribution and relation of meadow nematode, Pralylenchus pratensis to Fusarium wilt of cotton in (ieorgia, (abs.) Phytopath. 30 710, 1940. (The first report of the occurrence of Rolylenchulus reniformis, as identified by (i. Steiner, was first made from United States on cotton from Louisiana.)

76. Smith, A. I., and Taylor, A. I., Nematode distribution in the 1940 regional cotton-wilt plots, Phylopath. 41 (8) 771, 1941. (Rolylenchulus reniformis is reported from cotton and cowpeas from louisiana.)

77. Steiner, G, l'lant nematodes the grower should know, Proc. Stil Sri. Fla. 4-B 72-117, 1949. (Rotylenchulus reniformis is reported from Florida attacking coffee weed and tomato; from (ieorgia attacking Jarouemontia lamnifolia. Phylopath. $37(6)+41,1947$.)

78. - - Some little-known nematodes parasitic on roots, (abs.) Phytopalh. 57 (6) $4+1,19+7$. (Rolylenchulus spp. is reported from cotton, tobaceo, coffeeweed, and yera from the United States.)

79. - - 'Tres conferencias sobre nematología, Agr. Expt. Sta. Univ. P.R. Misc. Publ. 32, pl. i6, 1960. (Rolylenchulus reniformis was found abundantly about pigeonpea roots in Puerto Rico. The author suggests the presence of several species of this genus in Puerto Rico.)

30. Tanaka, 1., On the soil nematodes observed in tobacco fields, (prep. rept.) Kagoshima Tob. Wxpt. Sta. B. 9 59-62, 1954. ('Telylenchus nicoliana n. sp. described by Yokm and Tanaka in this paper; but this nematode was found to be Roty(enchulus sp.)

81. Tarjan, A. C., Cllecklist of Plant and Suil Nematodes: A Nomenclatorial Compilation, Univ. Fla. Press, (iainesville, Fla., pp. 1-200, 1960. (Includes Rolylenrlulus reniformis in his list of nematode species.)

82. Timm, R. W., The reniform nematode, a root parasite of Vicia faba, Pak. Rev. Agr. 2 (3) 135, 1956. (Broadbean was found infested with Rotylenchulus reniformis in Pakistan.)

83. Timm, R. W., and Mohmudul, A., Nematodes associated with commercial crops 
in East Pakistan. Agr. Pak. 11 (3) 1960. (Rotylenchulus reniformis found attacking pumelo, goud, hyathinth, bean and tomato in East Pakistan.)

84. Thorne, G., On the classification of the Tylenchida, new order (Nematoda, Phasmidia), Proc. Helminthol.Soc. Wash. 16 (2) 37-73, 1949. (The genus Rotylenchulus was included with Pratylenchus, Nacobbus, and Radopholus under the subfamily Pratylenchinae.)

85. —- Principles of Nematology, McGraw-Hill Book Co. Inc., New York, N.Y., pp. $244+7,1961$. (Rotylenchulus reniformis is included under the subfamily Paratylenchinae. Description, life, cycle, host list, and distribution are given.)

86. Van Werdt, L. G., Birchfield, W., and Esser, R. P., Observations on some subtropical plant-parasitic nematodes in Florida, Proc. Soil. Sci. Soc. Fla. 19 443-51, 1959. (Rotylenchulus reniformis was found parasitizing roots of mango trees. Several hosts are reported for what was believed to be a new species.)

87. Van Werdt, L. G., Martínez, A. P., and Esser, R. P., Results of a survey designed to determine the etiology of "lethat yellowing" of Cocos nucifera L., Proc. Fla. State Hort. Soc. 72 421-30, 1959. (An undescribed species of Rotylenchulus was found to be associated with the "lethat yellowing disease" of coconuts in Jamaica and Florida.)

88. Williams, J. R., Studies on the nematode soil fauna of sugarcane felds in Mauritius: Tylenchoidea, Occ. Paper Maur. Sug. Ind. Res. Inst. 4 1-30 1960. (A new species of Helicotylenchus was described from sugarcane roots. This species was transferred later to Rotylenchulus by Sher.)

89. Winslow, R. D., Some Aspects of the Ecology of Free-Living and Plant-Parasitic Nematodes, Nematology, Fundamentals and Recent Advances with Emphasis on Plant-Parasitic and Soil Forms, Univ. of N. C. Press, Chapel Hill, N.C.. pp. 341-405, 1960. (Discusses the life cycle and the semiendoparasitic feeding habits of Rotylenchulus.) 